Georgia: The GOP Tightens Its Grip

Charles S. Bullock, III

The presidential election season came to an early end in Georgia. Because the state was universally acknowledged as being safe for President Bush, the parties did not contest its Electoral College votes. The focus of the 2004 election cycle in Georgia came further down the ballot. The election marked the first time that Georgia elected a second Republican senator. The state had one of only three instances in which a House incumbent whose congressional seat had not been redistricted lost. Even more dramatically, Republicans took control of both chambers of the state legislature for the first time in more than 130 years.

\title{
Presidential Election
}

Since 1988, when Super Tuesday joined southern states in a presidential primary held early in the nominating season, Georgia has longed to be in a position to influence the selection of presidential nominees (Bullock 1991). In 1988 Georgia, along with the other Deep South states, failed to pick the winner when they gave plurality support to Jesse Jackson. Four years later, in an effort to enhance Georgia's impact on the nominating process, Governor Zell Miller convinced the legislature to move the presidential preference primary forward one week to make Georgia the first in the South (Bullock 1994). In 1992, Georgia became a player as it gave Bill Clinton his first primary win. Clinton's success in Georgia signaled that his marital problems and evasion of the draft during the Vietnam War did not disqualify him even in the conservative South.

Gov. Miller, who spoke on behalf of the Arkansas governor at the 1992 Democratic National Convention, continued to promote the candidacy of fellow southerner Clinton. The Clinton team invested heavily in Peach State television advertising, and Clinton, $\mathrm{Al}$ Gore, and the other Democrats campaigned in the state (Lockerbie and Clark 1994). These efforts succeeded as Clinton carried Georgia by fewer than five votes per precinct, making it the most hotly contested state in the nation. Clinton's plurality victory marked

Charles S. Bullock, III is the Richard B. Russell Professor of Political Science at the University of Georgia.

The American Review of Politics, Vol. 26, Spring, 2005: 43-63

(C)2005 The American Review of Politics 
the only instance since 1960 in which Georgia voted for a Democratic presidential nominee who was not a native son.

In 2004, Georgia gave President Bush a margin of more than 500,000 votes for a 58 percent victory, increasing his margin by 200,000 above his 2000 showing (Table 1). The size of Bush's 2004 victory easily eclipsed Ronald Reagan's reelection advantage of 367,000 votes, although it fell short of Richard Nixon's performance in Georgia when he demolished George McGovern by taking 75 percent of the vote and rolling up a 600,000-vote edge.

Table 1. Republican Vote Shares in Presidential, Senatorial, and Gubernatorial Elections, 1960-2004

\begin{tabular}{|c|c|c|c|}
\hline Year & Presidential & Senatorial & Gubernatorial \\
\hline 1960 & 37.4 & 0 & \\
\hline 1962 & & 0 & 0 \\
\hline 1964 & 54.1 & & \\
\hline 1966 & & 0 & $47.8^{*}$ \\
\hline 1968 & 30.4 & 22.5 & \\
\hline 1970 & & & 40.6 \\
\hline 1972 & 75.0 & 46.0 & \\
\hline 1974 & & 28.2 & 30.9 \\
\hline 1976 & 33.3 & & \\
\hline 1978 & & 16.9 & 19.3 \\
\hline 1980 & 42.9 & 50.9 & \\
\hline 1982 & & & 37.2 \\
\hline 1984 & 60.2 & 20.1 & \\
\hline 1986 & & 49.1 & 29.5 \\
\hline 1988 & & 59.8 & \\
\hline 1990 & & 0 & 44.5 \\
\hline 1992 & 42.9 & 50.6 & \\
\hline 1994 & & & 48.9 \\
\hline 1996 & 47.3 & 47.5 & \\
\hline 1998 & & 52.4 & 44.1 \\
\hline 2000 & 55.0 & 37.9 & \\
\hline 2002 & & 52.8 & 51.4 \\
\hline 2004 & 58.0 & 57.9 & \\
\hline \multicolumn{4}{|c|}{$\begin{array}{l}\text { *The Republican nominee won a plurality but Georgia law stipulated that if no candidate for gover- } \\
\text { nor won a majority, the decision would be made by the state legislature. Democrats dominated the } \\
\text { legislature and they selected the Democratic gubernatorial candidate. } \\
\text { Boldface indicates Republican victories. } \\
\text { Source: Compiled by author. }\end{array}$} \\
\hline
\end{tabular}




\section{Presidential Primary}

Other than adding votes to the 2004 Bush electoral margin, Georgia's only other moment on the presidential selection stage came during the primary season. Georgia continues to be among the earliest states to vote even though it has been overshadowed by larger states like New York and California. Georgia was potentially significant since it offered North Carolina Senator John Edwards a last prospect to keep his candidacy alive. Edwards' only victory had come in his native South Carolina a month earlier. His partisans hoped for a triumph in Georgia that would deny John Kerry a clean sweep on Super Tuesday.

Although Edwards represented one of Georgia's neighboring states, he lacked a deep or broad base of support in the Peach State. A Zogby poll conducted for the Atlanta Journal-Constitution in October 2003 showed Edwards at less than 4 percent among Georgia Democrats (Basu 2003). At that time the leading Democratic contenders in Georgia were Arkansas General Wesley Clark at 13 percent and U.S. Representative Dick Gephardt of Missouri at 11.5 percent. Edwards placed seventh, one notch behind John Kerry who had the support of five percent of the Georgia Democrats polled.

Two months later, the Howard Dean meteor was reaching apogee, and he led the field with almost 19 percent support among Georgia Democrats. Edwards had slumped to just 2 percent. Dean's rise also sapped strength from Kerry who had less than three percent. These Zogby polls showed approximately 40 percent of Georgia Democrats as undecided, which provided an opportunity for any candidate who could capture the imagination of the state's Democrats to rise dramatically.

Edwards' star began its ascent after his surprising second place finish in Iowa. A Zogby poll conducted a week before the Georgia primary showed Kerry leading Edwards 39-23 percent (Quinn 2004b). Kerry led Edwards among self-described Democrats by 49 to 20 percent. As continued to be true throughout the election cycle, the perception that he was the candidate most likely to defeat President Bush in November provided one of Kerry's strongest appeals among Georgia Democratic primary voters. Edwards showed greater strength among independents and Republicans who planned to vote in the open Democratic primary.

Edwards hoped to replicate his performance in Iowa where his support rose rapidly in the closing days of the campaign. He visited Georgia at the end of February and took heart from an American Research Group poll that showed him only eight points behind Kerry. The North Carolina senator expressed optimism in his Georgia visit, saying with regard to the latest polling data, "It sounds like Wisconsin to me. I'm a good closer." The reference to Wisconsin underscored his drawing to within six percentage points 
of Kerry there after trailing substantially. However, a Zogby poll released on February 29 continued to show Edwards 19 percentage points behind Kerry (Quinn 2004a).

Although Edwards raised more than $\$ 500,000$ from Georgians, an amount roughly twice that raised in the state by Kerry, the Massachusetts senator had a larger television presence in the Peach State (Galloway 2004). Kerry ran ads in all six Georgia media markets and by late February had spent three times as much on Atlanta television as had his North Carolina opponent.

The AFL-CIO, which engaged in get-out-the-vote activities, supported Kerry. He also had an edge among African-American leaders, including the most powerful black state legislator. Kerry's fellow Vietnam-veteran colleague, former Senator Max Cleland, helped with the frontrunner's efforts in Georgia. Former Governor Roy Barnes, a trial lawyer, was the most visible surrogate for the wealthy North Carolina attorney turned senator.

Edward's primary performance improved substantially over the last Zogby poll. But while Edwards eliminated much of the gap, he came up short. The boyish-looking Tar Heel senator finished second to Kerry with 41 percent of the vote, six points behind the frontrunner-just like in Wisconsin. With the air leaking rapidly from the Edwards' balloon and no prospect for a patch, the trial lawyer ended his candidacy shortly after Georgia.

\section{General Election}

The only attention given Georgia by Bush and Kerry, aside from the Democratic primary, was to treat the state as a cash cow. In June 2003, President Bush came to Reynolds Plantation, a resort about 70 miles east of Atlanta, and raised \$2.5 million. Seven months later, an Atlanta event generated another \$1.3 million for the President's reelection (Scott 2004). Democrats had a fundraiser at the home of Ann Cox Chambers, the Atlanta billionaire who, along with her sister, owns a large chunk of Cox communications, which includes Georgia's leading newspaper, The Atlanta JournalConstitution, and television station WSB-TV in Atlanta. Vice President Dick Cheney ventured into the state to host fundraisers for congressional candidates.

The exit polls showed that George Bush attracted the same kinds of voters in Georgia as nationwide, but in Georgia he achieved phenomenal majorities among certain segments of the electorate. (Unless otherwise indicated, data on various demographic and other voter groups are drawn from the exit poll data from the 2004 National Election Pool, conducted by Edison Media Research and Mitofsky International.) For example, Bush got 96 percent of the vote from white Protestant conservatives who made up 
26 percent of the electorate. While Bush drew near unanimous support from Christian conservatives, his appeal was much broader. Approximately a quarter of the Georgia electorate cited moral values as the most important issue in the presidential election, and, of those voters, 88 percent supported the President. Those for whom the most important issue was terrorism constituted another strong constituency for Bush: more than one in five voters cited that issue, and 89 percent of them voted to reelect the president.

In terms of the most important quality cited by voters, 12 percent mentioned religious faith, and here President Bush received almost unanimous support, taking a phenomenal 98 percent. Of the 22 percent of Georgia voters who thought having a strong leader was the most important quality, 91 percent voted for the President. Another 13 percent cited having a clear stand on the issues as the most important quality for a president, and this group gave Bush 78 percent of its votes. Combining these three issues accounts for 47 percent of the electorate, and the President drew remarkably consistent support from these voters.

Kerry attracted 94 percent of the vote from the 23 percent of the electorate eager for change. Of the 18 percent who considered the economy and jobs as the most important issue, more than 4 out of 5 voted for the challenger as did 82 percent of the four percent of the electorate who identified healthcare as the most important issue. Although the President explained the invasion of Iraq as part of the war on terrorism, Kerry got 73 percent of the vote from the 13 percent of Georgia voters who considered Iraq the most important issue.

Color-coded maps showed Bush red states covering most of the nation. Red also dominated the map of Georgia as Bush carried 133 of the 159 counties. John Kerry carried three counties at the center of the Atlanta metro area, in two of which most registered voters are black. The only other Kerry county in north Georgia, Clarke, is the home of the University of Georgia and has a much larger liberal component in the electorate than the 16 percent liberal found statewide. The remaining counties that mustered Democratic majorities contain the state's other urban centers and a string of rural counties that run diagonally across the state near the fall line. The rural counties are part of the black belt, an area noted for its rich soil and productive agriculture. These counties continue to have large black populations, a holdover from when cotton was king. This partisan pattern closely resembles the successes of each party in the 2000 presidential election and in the 2002 gubernatorial election.

As another perspective on Bush's strength in Georgia, his percent of the vote increased from 2000 in all but 13 counties. The counties that failed to demonstrate an increase included all but one of the counties housing a city at the center of a metropolitan area. In almost half of Georgia's counties (77) Bush ran at least five percentage points ahead of his 2000 showing. 
Table 2. Regression Analysis of the 2004 Republican Presidential and Senate Vote in Georgia Counties

\begin{tabular}{|c|c|c|c|c|}
\hline & \multicolumn{2}{|c|}{ Bush Support } & \multicolumn{2}{|c|}{ Isakson Support } \\
\hline & Model 1 & Model 2 & Model 1 & Model 2 \\
\hline Black Registration & $\begin{array}{l}-.745 * * * \\
(.030)\end{array}$ & $\begin{array}{l}-.398 * * * \\
(.034)\end{array}$ & $\begin{array}{l}-.677 * * * \\
(.033)\end{array}$ & $\begin{array}{l}-.301 * * * \\
(.035)\end{array}$ \\
\hline Population Growth & $\begin{array}{l}.045^{*} \\
(.017)\end{array}$ & $\begin{array}{l}.001 \\
(.014)\end{array}$ & $\begin{array}{l}.034 \\
(.019)\end{array}$ & $\begin{array}{l}-.017 \\
(.015)\end{array}$ \\
\hline Racial Conservatism & $\begin{array}{l}.060 \\
(.043)\end{array}$ & $\begin{array}{l}.174 * * * \\
(.020)\end{array}$ & $\begin{array}{l}.062 \\
(.048)\end{array}$ & $\begin{array}{l}.151 * * * \\
(.021)\end{array}$ \\
\hline Traditional Republicanism & $\begin{array}{l}-.160^{* *} \\
(.057)\end{array}$ & - & $\begin{array}{l}-.114 \\
(.063)\end{array}$ & - \\
\hline Contemporary Republicanism & - & $\begin{array}{l}.557 * * * \\
(.050)\end{array}$ & - & $\begin{array}{l}.633 * * * \\
(.053)\end{array}$ \\
\hline Constant & .777 & .329 & .749 & .282 \\
\hline Adjusted $\mathrm{R}^{2}$ & .90 & .94 & .85 & .92 \\
\hline$* \mathrm{p}<.05 \quad * * \mathrm{p}<.01 \quad * * * \mathrm{p}$ & $<.001$ & & & \\
\hline \multicolumn{5}{|c|}{$\begin{array}{l}\text { Note: The dependent variables are George Bush's and Johnny Isakson's percentages of the total } \\
\text { vote. Population growth is measured as the percentage change in the population from } 1990 \text { to } 2000 \\
\text { as calculated by the U.S. Census Bureau. Racial Conservatism is measured as the percentage vote for } \\
\text { George Wallace in the } 1968 \text { presidential election. Traditional Republicanism is measured as the } \\
\text { Nixon share of the } 1968 \text { vote. Contemporary Republicanism is measured as the average Republican } \\
\text { share of the vote across five statewide elections in } 2002 \text {. } \\
\text { Sources: Data compiled by the author. Election results are taken from data available from the } \\
\text { Georgia Secretary of State. }\end{array}$} \\
\hline
\end{tabular}

Table 2 presents two multivariate models of support for President Bush. The first model includes the vote share for Richard Nixon in 1968, a variable that has been used as a measure of traditional GOP strength. This measure was a strong positive correlate of GOP support in the 1992 and 1996 presidential elections (Lockerbie and Clark 1994; Clark and Lockerbie 1997) but in 2004 the relationship was negative and statistically significant. The black registration figure shows that Bush fared worse when African Americans constituted larger shares of the electorate. This model also shows the Bush vote to be greater in fast-growing counties.

In the second model, the traditional measure of GOP support is replaced by the average share of the GOP vote from five 2002 statewide contests. This contemporary partisan measure is strongly related to the Bush vote. President Bush also ran better in counties that supported George Wallace in 1968 but he performed poorly in heavily black counties. The 2004 presidential results are in line with state voting two years earlier but, 
quite unlike party voting patterns at the time, the GOP was becoming a factor in Peach State politics. The shift in the relationship with traditional GOP presidential strength comes in 2000 (Bullock 2002) and has persisted.

\section{U.S. Senate}

The contest to fill the Senate seat to which Zell Miller was appointed in 2000 underscored the declining fortunes of the once dominant Democratic Party. Unlike the GOP, which launched a sophisticated program for identifying targets of opportunity and then recruited candidates to exploit the opportunity (Bullock and Shafer 1997), Georgia's traditional governing party continued to expect that quality candidates would emerge with little prompting from party headquarters. Until recently, the absence of a candidate recruitment program did not hurt the Democratic Party. In 1972, when the appointed replacement tried to retain the Senate seat held by Richard Russell for 38 years, 14 challengers came forth in the Democratic primary, including a former governor. Even as recently as 1996 (when Sam Nunn stepped down from his senate seat), while only one Democrat sought the nomination, the nominee was the long-time Secretary of State, Max Cleland, a candidate so formidable that he scared off other possible Democrats. The party also had multiple, attractive candidates come forward in 1998 to contest open seats for governor and lieutenant governor.

\section{Democratic Primary}

In 2004, however, the two Democrats best positioned to claim the Miller seat, Lieutenant Governor Mark Taylor and Secretary of State Cathy Cox, spurned repeated requests to run. They opted to sit on the sidelines glaring at one another while laying plans for the 2006 gubernatorial contest. Several other high visibility Democrats also declined to run, including former congressman and UN ambassador Andy Young and the daughter of former Senator Sam Nunn. A poll commissioned by EMILY's List showed Atlanta's first woman mayor, Shirley Franklin, leading both of the GOP members of Congress who had announced their candidacies (Frankston 2003), but Franklin quickly took herself out of consideration.

Finally, one of Georgia's five Democratic members of Congress, freshman Denise Majette stepped forward. Her entry, however, did not generate great enthusiasm. High-profile Democrats, including former President Jimmy Carter, continued to cast about for someone else. Increasing attention focused on Cliff Oxford, a "dot-com" millionaire who had recently sold his software firm. Oxford displayed Hamlet-like consistency while contemplating a run. On the day before candidate qualifying ended, Oxford announced 
that he had decided to pass up a Senate bid. But the next day, just 15 minutes before qualifying ended, Oxford, who had chartered a jet to bring him to Atlanta from Orlando, rushed into the Capitol and plunked down his qualifying fee.

Oxford, whose political resume consisted of an unsuccessful run for a congressional nomination, had the virtue of being able to self-finance his campaign. Offsetting this asset were an ex-wife's allegations of physical abuse (Smith 2004b). On the stump Oxford came off as Johnny One-note. He displayed mastery over only one issue: job out-sourcing. The former entrepreneur repeatedly pointed out that, rather than out-source jobs with his software company, he had hired additional workers in South Georgia.

Service in the U.S. House is one of the two most frequently followed paths to the Senate. An asset that a member of Congress typically brings to a statewide contest is a base of support. Having represented the share of the state's population that lives in the congressional district provides name recognition among a set of voters and a record of accomplishment on which to campaign. Majette's candidacy did not bask in the usual advantages of a House member trying to move up to the Senate. As a first term member of the minority party in Congress, she could point to few accomplishments. Even more troubling, many of her constituents opposed the Senate bid. The opposition derived from the fear that her run for the Senate would allow the controversial Cynthia McKinney, who Majette had defeated in the Democratic primary in 2002, to reclaim the congressional seat. Republicans who had backed Majette's congressional candidacy pledged continued support should McKinney try to unseat her; but, if she ran for the Senate, they were already committed to Republican Johnny Isakson. Majette, reportedly believing that she had been called upon by God, ignored those seeking to dissuade her, and she plunged into the Senate sweepstakes (Smith 2004a).

If Oxford and Majette were lightweights, featherweights composed the rest of the Democratic field. The assortment of six other candidates included only one with office-holding experience, Mary Squires, who vacated a state Senate to run. This large, if undistinguished, field prevented anyone from receiving the 50 percent of the primary vote needed for nomination. Especially telling was that one-seventh of the voters who asked for Democratic ballots did not bother to vote for any of the Senate candidates. It is likely that many voters could recognize none of the candidates' names or that they recognized only Oxford and found him unattractive because of the stories surrounding his divorce.

Majette, who ran no television ads, still managed to lead the primary field with 41.3 percent of the vote in the face of Oxford's self-financed television. Despite spending $\$ 1$ million on television, Oxford was such an unappealing candidate that he ran less than seven percentage points ahead of 
Jim Boyd, a perennial candidate who refused to participate in candidate forums but whose multiple unsuccessful campaigns provided a degree of name recognition.

Majette won the runoff with 59.4 percent of the vote. Despite having no television advertising, she triumphed because of support from AfricanAmerican ministers and political leaders excited by the opportunity to send the first of their race to the Senate from Georgia. Majette rolled up a margin of almost 26,000 in DeKalb County which she had represented in Congress. Much of the rest of Majette's 51,000 vote margin came from Fulton County where she beat Oxford by almost 23,000 votes. Outside of metro Atlanta, Oxford had a small majority in the runoff.

\section{Republican Primary}

Unlike on the Democratic side where no top-tier candidate came forward, the Republican primary attracted three aspirants, any one of whom was more formidable than the best that the Democrats could muster. Johnny Isakson who represented a suburban congressional district on the north side of Atlanta jumped into the contest immediately after Zell Miller announced his retirement. For months, Isakson had the field to himself, as he went about raising funds and lining up support. Isakson had statewide name recognition as a result of losing by about 10 percentage points to Miller in the 1990 gubernatorial contest and then failing to win the Republican Senate nomination in 1996.

In the late spring of 2003, another member of Congress, Max Collins, whose district lay on the southwest side of Atlanta and extended down to Macon also entered the GOP contest. Collins staked out the more conservative position, giving Isakson free rein in the middle. Collins hoped to polarize the electorate, and he counted on conservatives dominating the Republican primary.

The first problem with Collins' approach was that he did not have the right end of the philosophical spectrum to himself. Herman Cain, an African American who had returned to Georgia after as stint as the CEO of Godfather's Pizza, vied with Collins to be the most conservative candidate. Collins' distaste for aggressive fundraising proved to be a second handicap. His former staffers report that he refused their entreaties to spend more time dialing for dollars. Isakson had no such qualms, and Cain was wealthy enough to self-finance his campaign. Collins also had a flawed strategy for spending his most precious resource, his personal appearances. According to those who worked on his campaign, Collins felt most comfortable campaigning in his congressional district. This decision did little to broaden his appeal since, if he had any strength, it would be in the counties he had represented 
during his dozen years in Congress. Moreover, if he hoped to win, he needed to concentrate on the suburban counties north of Atlanta that would provide a disproportionate share of the GOP primary voters.

Isakson romped over his divided opposition, winning 53.3 percent of the vote and thereby avoiding a runoff. Cain finished ahead of the slumping Collins, and, based on his ability to attract 26.2 percent of the vote, Cain is mentioned as a future prospect for statewide office.

Isakson's ability to win the nomination without a runoff shed light on changes in the Republican primary electorate. While locked in a tight battle for the Republican senatorial nomination in 1996, Isakson took the risky approach of articulating a moderate position on abortion. He released a television ad that showed him with his wife and college-age daughter. Isakson expressed his own distaste for abortion but went on to say that, "I trust my wife, my daughter and the women of Georgia to make the right choice" (Tharpe 2004).

Cain and Collins had jousted for recognition as the most reliable opponent of abortion as they attacked Isakson while bragging of their own commitment to the agenda of abortion opponents. Isakson's 1996 ad outraged Christian conservatives and many had vowed to never support him for any office. Georgia Right to Life, which tolerates abortion only to save the mother's life, gave a split endorsement to Isakson's opponents. But, significantly, another major force for religious conservatives, the Christian Coalition, did not become involved in the Republican senatorial primary. While in the past, it would have found Isakson's abortion stands troubling, it largely sat out the election. Even in the midst of the primary campaign, when Isakson voted to permit American military women stationed abroad to pay for abortions in military hospitals, it failed to draw the Christian Coalition into the campaign.

Estimates are that Christian conservatives account for about 30 percent of the GOP primary electorate. While this is a sizable component of that electorate, it is insufficient to dictate the outcome-a loss of influence from a decade earlier when they might well have blocked a candidate who took Isakson's position on abortion. The influence of abortion opponents has weakened as greater numbers of more moderate voters come over from the Democratic primary. ${ }^{1}$ The 2004 Republican primary attracted almost 200,000 more voters than eight years earlier when Isakson lost.

\section{General Election}

Isakson entered the general election campaign as the heavy favorite. His moderate policy stands made him acceptable to many independents and some Democrats. For the latter, he appeared to be in the tradition of other 
Georgia senators such as Dick Russell, Herman Talmadge, and Sam Nunn. Moreover, he had the advantage of whatever coattails the party's presidential nominee provided. Finally, the Georgia ballot contained an amendment to the state Constitution designed to ban gay marriages. This amendment would spur turnout, and Georgia has far more religious conservatives than partners in non-traditional relationships.

Although polls during much of the campaign showed Isakson hovering around 50 percent or even slightly below, he consistently ran well ahead of his Democratic opponent. With Majette floundering, Isakson largely ignored her. While Majette sniped at her Republican opponent, the liberal voting record she had established during her term in Congress disqualified her in the eyes of many conservative voters.

Majette did manage to raise enough funds to have a presence on television during the closing days of the campaign. Her effort, however, paled in comparison with the massive television budget that had enabled Isakson to advertise heavily on television for months.

Isakson won with 58 percent of the vote, rolling up a massive majority of 577,000 over Majette. Isakson got 77 percent of the white vote but only 11 percent of the black vote. He carried all but 19 of Georgia's 159 counties. Isakson took everything except the counties at the center of metropolitan areas and scattered rural counties with high concentrations of African Americans. Despite a record turnout in which blacks cast 25 percent of the ballots and gave 89 percent of those votes to Majette, she just managed 40 percent statewide.

Isakson's campaign went a long way toward eliminating the gender gap. While Republicans in Georgia have been able to carry the bulk of the male vote for quite some time, during the 1990s they often came up short because of their weakness among female voters. While men continued to be more supportive of Isakson than women, he took a commanding 55 percent of the female vote to go along with a 62 percent share of the male vote.

Isakson's win showed broadly distributed strength as he won majorities with every age group, although his vote share did increase with voter age. $\mathrm{He}$ also got majorities from all income groups earning at least $\$ 30,000$. He won 58 percent of the vote among independents. He came close to getting unanimous support among Republicans (95 percent of whom voted for him), and he siphoned off 15 percent of the Democratic vote. Isakson was the candidate of choice for 93 percent of the white conservative Protestants while Majette eked out a narrow 52 percent victory among whites who were not conservative Protestants. Isakson got at least 80 percent of the vote among exit poll respondents for whom the most important issues were taxes, terrorism, or moral values. While Majette commanded majorities among voters for whom education, Iraq, healthcare, and the economy and jobs were 
the issues of greatest concern, the set of issues on which Majette thrived accounted for only 40 percent of the electorate.

The voting patterns in the Senate election in Table 2 are similar to those reported for the presidential election. Isakson ran worse in heavily black counties. Model 2 shows Isakson attracting larger shares of the vote in counties where his party performed well in 2002 and in counties that backed George Wallace in 1968. In the first Isakson model, population growth and the Wallace vote are positively related to GOP support but come up just short of being significant at the .05 level. As in the model for George Bush, support for Isakson varied inversely with the 1968 Nixon vote, although the coefficient just misses being significant at the .05 level in the Senate model.

\section{U.S. House}

While Republicans won the presidential and U.S. Senate contests by landslide proportions, Georgia provided one of the most competitive congressional elections in the nation. In the wake of the 2001 redistricting, very few congressional districts anywhere in the nation are evenly balanced between Democrats and Republicans. The Democrats who drew Georgia's map had no intention of creating competitive districts and instead thought they had devised a plan under which Democrats would take seven districts while packing Republicans into six districts. To take seven districts, Democrats needed to win both of the seats the state had gained as a result of the 2000 Census (Georgia had experienced a 26 percent population growth during the 1990s). Democrats would also need to dispossess two of the sitting Republican members of Congress.

Democrats drew the two new districts to include populations that were about 40 percent African American. It was widely accepted that for an African American to win a legislative seat, a majority of its voting-age population needed to be black (Lublin 1997). Thus it is likely that when drawing these seats Democrats anticipated that the black concentration would suffice to prevent the election of a Republican and also be insufficient to elect a black Democrat. This would allow white Democrats to win in these districts. In 2002 that expectation proved accurate in neither district. In the primary in the 13th district, David Scott, a black state senator, defeated a white senator, the former white head of the state Democratic Party, and a black. In the 12th district, a bacon slice that includes Democratic concentrations in Athens, Augusta and Savannah, Democrats also nominated an African American. While Scott proved to be an outstanding candidate in the 13th district in 2002, Champ Walker, the nominee in the 12th district, turned out to be unelectable. Democrats picked perhaps the only person who could not win. Walker had a longer arrest record (five incidents) than public service record 
(no elections). In addition to having a number of blemishes on his record, Walker showed little command of issues at candidate forums and frequently missed them altogether. Even though Democrats had expected, based on past electoral results, that their nominee would get approximately 58 percent of the vote, Republican Max Burns, a south Georgia professor, won in 2002 with 55 percent of the vote.

Since the 12th district was drawn to be safely Democratic, the loss stung, and the Democratic congressional leadership joined Georgia Democrats vowing to make every effort to reclaim what they saw as rightfully theirs. Four Democrats came forward to contest the 2004 nomination, including a council member from Athens, a former state senator, and a former congressional nominee. Athens attorney John Barrow, who had served for 14 years on the city commission, quickly hired a fundraiser and withdrew from his law practice to devote full time to the effort. The fundraiser generated more than $\$ 850,000$ for the primary, far more than any of his opponents, and this allowed Barrow to be on television in Augusta and Savannah, the two television markets in his district.

Barrow's leading opponent, former Senator Doug Haines, tried to replicate the campaign that had elected him to the state Senate in 2000 and concentrated on building a grassroots organization. The challenges of creating a grassroots organization that covers almost 650,000 people, spread across a 200 mile-long district proved too difficult. With little money for television advertising and having to share his Athens base with Barrow, Haines came up far short as Barrow won an outright majority in the primary.

With the primary behind him, Barrow continued to emphasize fundraising. He ultimately raised $\$ 1.8$ million, which, although only about twothirds as much as the incumbent generated, sufficed to make the Democrat fully competitive in the general election.

Both Barrow and Burns had sufficient funds to advertise extensively on Augusta and Savannah television. To improve Barrow's prospects in what the Democratic Congressional Campaign Committee saw as their best chance to defeat a Republican incumbent, the DCCC augmented Barrow's own impressive fund raising with the infusion of $\$ 750,000$. According to a DCCC operative, "We threw the kitchen sink at this race." If Democrats had any hope of regaining majority status in the U.S. House of Representatives, it would be necessary to do well in the handful of competitive districts.

Particularly effective for Barrow were attacks by the candidate and the DCCC directed at Burns for his support of the national sales tax proposed by fellow Georgia Republican John Linder. While Linder proposed eliminating the Internal Revenue Service and the income tax and replacing it with a national sales tax of about 23 percent, Democratic ads suggested that the national sales tax would be in addition to current taxes. Barrow sought to fan 
class jealousies by noting that the Linder proposal would eliminate corporate taxes. The Democratic advertising proved so effective that some Burns supporters called their candidate to see if it were true that he proposed to saddle them with a huge new tax burden. The Democratic ads suggesting that Burns backed a new tax outraged the incumbent, who like most Georgia Republicans prides himself for being anti-tax.

A second line of attack criticized Burns for not doing enough to hold down the cost of healthcare. Barrow repeatedly criticized the incumbent for blocking the importation of less expensive prescription drugs from Canada.

After an early poll showed that most voters in the district knew little about Barrow, Burns set out to create a negative image for the challenger before he could fashion his own positive one. To this end, the incumbent charged that his opponent had been anti-business while serving on the Athens-Clarke County commission. Burns also sought to divorce Barrow from some likely supporters. Georgia was one of the states to ratify a constitutional amendment banning gay marriage in November 2004. During the primary when trying to maximize support among Democratic voters, Barrow had indicated opposition to the state ban as well as the ban proposed in Congress. During the general election, after being warned that support for gay marriage might doom his candidacy, Barrow shifted his position. He continued to oppose efforts to write a ban in to the state Constitution but said he supported a federal ban. Burns used the inconsistency to echo a theme that President Bush's campaign directed at John Kerry charging that the Democrat had flip-flopped and therefore could not be trusted.

Since the population of the 12th congressional district is approximately 40 percent African American, should a Republican do as poorly with that set of voters as most Republicans do in the South, an overwhelming share of the white vote would be necessary to win. Burns recognized this problem and courted black voters by hiring a black staffer and frequently visiting black congregations. Burns went after the black vote well before Barrow did, which suggested to some that the Democrat was taking African-American voters for granted. In the closing weeks of the campaign an AfricanAmerican staffer sent down from Washington, DC, stepped up Barrow's efforts at courting the black vote, and Barrow ultimately obtained approximately 90 percent of their votes.

The 12th district was designed to give a Republican about 42 percent of the vote. In losing to Barrow, Burns managed 48 percent in his reelection bid which suggests that incumbency added approximately six percentage points to his vote share - an increment in keeping with estimates of the value of incumbency. 


\section{McKinney Returns}

The 2004 election saw firebrand Cynthia McKinney return to the House. McKinney, who had represented an eastside metro Atlanta district for a decade, lost the 2002 Democratic primary. As noted earlier, the loss came at the hands of Denise Majette who attracted about 95 percent of the white vote while McKinney retained more than 80 percent of the black vote (Bullock et al. 2003). McKinney had become a lightening rod who attracted widespread white opposition because of what they perceived to be outrageous comments. The straw that broke the camel's back came when she claimed that President Bush had been negligent prior to September 11 because his family and friends stood to benefit economically in the wake of the attack on the World Trade Center Towers.

As McKinney sought to regain the 4th district seat, she faced several credible opponents led by three current state senators (two African Americans and one white). The white senator had previously served as the chief executive for DeKalb County which contains almost all the 4th congressional district. Another white contender, Kathy Woolard, gave up her position as head of the Atlanta city council. Woolard, who is a lesbian, drew financial support from the sizable gay and lesbian community in Atlanta, although many of them did not live in the congressional district.

McKinney ran a far different race in 2004 than she had in previous years. She did nothing to attract media coverage and did not attack her opponents. While she ran something of a stealth campaign, the two leading white candidates exchanged charges. To the surprise of virtually everyone, McKinney won nomination without a runoff as she finished with just under 51 percent of the vote while the two whites each had about 20 percent. McKinney's success demonstrated that even in a contest with two senior black senators, she remained the overwhelming choice of African American voters. While many white voters found her comments to be outrageous, her practice of "speaking truth to power," as she liked to say, found near universal favor in the black community.

\section{State Legislative Elections}

Republicans had been winning majorities of the popular vote for the House and the Senate beginning with the 1996 election. In some election years, they had gotten as much as 55 percent of the popular vote but had struggled to win even 40 percent of the seats. Democrats' realization that they no longer commanded a majority of the Georgia electorate explains their extraordinary set of gerrymanders adopted in 2001. The comments made by national political observer Stuart Rothenberg concerning the state's 
congressional plan are equally applicable to the state legislative maps. "[T]he map passed in Georgia more than three years ago isn't normal," Rothenberg (2005) wrote in Roll Call. "The plan passed in 2001 was and remains indefensible - an example of partisanship and common sense run amuck."

In 2003, Republicans partially overcame the gerrymander, for the first time in 130 years controlling a majority in one chamber of the Georgia General Assembly; they achieved a two-vote majority after four Democratic senators switched parties. These defections angered the Democrats who vowed to reclaim the Senate while retaining their advantage in the House. Democrats might have achieved their objectives had not their 2001 gerrymander been invalidated by a federal court early in 2004 . When the legislature failed to replace the maps, a three-judge federal panel had new maps drawn that sought to avoid partisan bias. Since they replaced a Democratic gerrymander, the 2004 maps removed the advantages Democrats had built in. The changes created numerous open seats which also worked to the advantage of the GOP since their nominees would not have to unseat an incumbent.

In the judge-drawn plan, the success that Republicans had enjoyed with the voting public finally translated into legislative seats. The GOP added four more Senate seats to gain a comfortable 34-22 seat advantage. After years of getting less than a proportionate share of the Senate, Republicans enjoyed a taste of the bonus that usually goes to the party winning a majority of the votes. Their 57 percent of the popular vote for senators translated into 61 percent of the seats. In the House, Republicans stunned observers in both parties when they registered a net gain over 2002 of 21 seats. This gave the GOP 96 of the 180 seats and the margin soon increased when three Democrats switched parties.

Republicans achieved majority status in the General Assembly by dominating types of districts where in the past they had struggled to break even. The pattern for years has been for Republican success to be inversely related to the proportion black in legislative districts in a manner similar to the correlates for Bush and Isakson reported in Table 2. Republicans rarely won districts more than 30 percent black but dominated districts less than 10 percent black with districts 10-30 percent black being competitive (but favoring Democrats as the percentage increased). In 2002 Republicans had unprecedented success in more heavily African-American jurisdictions; in his gubernatorial race Republican Sonny Perdue carried all but three of the 110 counties in which black registration was less than 33 percent in his upset victory over Democratic Governor Roy Barnes, and Republican Saxby Chambliss defeated Democratic Senator Max Cleland in 103 of these counties. 
As impressive as the Republican showing was in the 2002 statewide contests, the GOP did even better in the 2004 state Senate elections by winning all 33 districts in which blacks accounted for less than 30 percent of the registrants. Black registration was almost a perfect determinate of partisanship as Democrats won all but one of the 23 districts more than 30 percent black in registration. Republicans' success in districts with moderate concentrations of African Americans result from growing support among white voters as partisan divisions come to parallel racial lines.

In the House the 30 percent black registration figure was not as clear a dividing line. Democrats continued to win 21 of the 114 House districts less than 30 percent black in total registration. However, three Democrats who triumphed in these districts changed parties almost immediately after the election. The success that Democrats enjoyed in these districts with relatively small black registration figures is largely due to the presence of wellentrenched incumbents. Since the voters in these districts generally support Republicans in statewide contests, as the Democrats retire, Republicans are likely to expand their ranks in these districts.

\section{Conclusion}

In 2004 Georgia Republicans expanded and consolidated their positions and extended their political influence further down the ballot. Aside from the successes enjoyed by Georgian Jimmy Carter in his two presidential bids, Georgia has voted for a Democrat for president only once in the last 44 years. In 2004, for the first time ever, Georgia voters simultaneously gave their Electoral College votes to a Republican while electing a Republican senator. The aftermath of this election marks the first time in state's history that both of the state's senators have been Republicans. The two senators join Sonny Perdue who won the governorship in 2002 ending 50 consecutive gubernatorial elections won by Democrats. Republicans currently hold 9 of the 15 statewide offices.

Since 1994, Republicans have filled most of Georgia's congressional seats. Even with the loss of the 12th District to Democrat John Barrow, Republicans retain seven seats. The 7-6 GOP advantage in the congressional delegation underrepresents Republicans who won 61.5 percent of the votes in the 2004 congressional elections. As this is being written the Republican legislature has before it redistricting plans that might net their party an eighth seat.

The legislature that convened in 2005 is the first in modern times controlled by the GOP, and their dominance seems likely to persist through the remainder of the decade. While there may be a district or two in which a Republican is vulnerable, there is at least one Democratic Senate seat that a 
Republican might win should the incumbent step aside. Republican prospects are even brighter in the House where approximately 15 seats continue to be filled by Democrats even though these electorates usually vote Republican for higher offices. Some of these districts may change parties in 2006 if the Democratic incumbents file for reelection as Republicans. Several of these Democratic legislators may have been laying the groundwork for that shift when they voted for the Republican candidate for speaker rather than remaining loyal to their own party. Otherwise, the districts may shift into the GOP column when the Democratic incumbent retires or Republican challengers may actually wrest some of these seats away from the Democrats.

The shift in party control at all levels, except for county offices in which Democrats continue to dominate, reflects the change in the state's party loyalties. The exit polls for 2004 for the first time showed Republicans having a plurality in the electorate. Over the course of 12 years, Georgia party loyalties have demonstrated a complete reversal. In 1992, exit polls showed Democrats as the party of 42 percent of the voters while 34 percent identified themselves as Republicans. In 2004, Republicans claimed the loyalty of 42 percent of the electorate while Democrats had slipped to 34 percent.

Democrats confront the future without plurality support for the first time at least since the re-enfranchisement of Confederate sympathizers who lost the suffrage in the immediate aftermath of the Civil War. As Democrats begin life as the minority, they are ill-prepared to reclaim their long-time hegemony. For most of the last 20 years, Republicans have bested Democrats in candidate recruitment and grassroots organizing. GOP candidate recruitment has been a high priority for almost two decades (Bullock and Shafer 1997). During his tenure as executive director of the state Republican Party, Ralph Reed perfected grassroots mobilization as part of the Republican's national "72-Hour Campaign."

Democrats will need to copy some pages from the Republican preelection playbook and also convince larger numbers of Georgians that the Democratic Party represents their interests. This challenge became more difficult as moderates have joined the conservative exodus to the Republican Party (Black and Black 2002). With the loss of conservative ballast, the Democratic ship lists further to the left. Republicans in Georgia as in many other southern states reiterate the charge that Democrats are too liberal for the state. The constant repetition of that theme has convinced many voters that it is true. To understand the magnitude of the problem that creates for Democrats, consider that only about one-sixth of the Georgia electorate thinks of itself as liberal while more than 40 percent identify themselves as conservatives. If the electorate perceives the Republican nominee as a conservative and the Democrat as a liberal, the Republican begins the election 
within striking distance of a majority while the Democrat must capture a large majority among the ranks of the moderates to win statewide.

The 2004 elections in Georgia provided further proof of the accuracy of at least some of the criticisms voiced by outgoing Senator Zell Miller. In his stinging rebuke to his own Democratic Party, Miller (2003) noted that the National Democratic Party had become an albatross for statewide Democratic candidates in the South. With a Massachusetts liberal at the top of the ticket and a liberal African-American running for the Senate, the most visible Democrats stood far to the left of the bulk of the Georgia electorate in 2004.

One of the points made by Miller is that because of the ideological distance between the National Democratic Party and most Georgia voters, a Democrat running statewide in Georgia does not dare to invite party leaders to the state. Joining John Kerry among the Democrats absent from Georgia were Hillary Clinton and Ted Kennedy. Nancy Pelosi, minority leader in the House did make one appearance in Atlanta after John Barrow dissuaded her from appearing in the congressional district he was contesting. Barrow welcomed the assistance of a Pelosi staffer but dared not have the liberal California congresswoman join him on the campaign trail.

In contrast, Vice-President Dick Cheney came to the state and headlined a successful fundraiser for Barrow's opponent. Rudy Giuliani and the Republican Senate Majority Leader, Bill Frist of Tennessee, also campaigned for Republicans in Georgia.

The winds of partisan change reached such velocity in Georgia that some officeholders lost their anchors. Isakson boasted that he had the endorsements of nine current Democratic state legislators, five former Democratic state legislators and 13 local Democratic officeholders (Isakson press release 2004).

In a particularly striking illustration of the accuracy of Miller's claims concerning with whom Democrats were willing to consort, when George Bush came to Atlanta for a fundraiser in January 2004, eleven state House Democrats joined in the celebration (Scott 2004). At least one of these made heavy use of the picture he had taken with the Republican president in his reelection literature.

\section{NOTES}

\footnotetext{
${ }^{1}$ Georgia does not have partisan registration. Voters can request either party's ballot when they arrive to vote in the primary.
} 


\section{REFERENCES}

Basu, Moni. 2003. Poll Shows Dean No. 1 with Georgia Democrats. Atlanta Journal Constitution, December 19.

Black, Earl, and Merle Black. 2002. The Rise of Southern Republicans. Cambridge, MA: Harvard University Press.

Bullock, Charles S., III. 1991. The Nomination Process and Super Tuesday. In The 1998 Presidential Election in the South: Continuity Amidst Change in Southern Party Politics, eds. Laurence W. Moreland, Robert P. Steed, and Tod A. Baker. New York: Praeger.

Bullock, Charles S., III. 1994. Nomination: The South's Role in 1992 Nomination Politics. In The 1992 Presidential Election in the South: Current Patterns of Southern Party and Electoral Politics, eds. Robert P. Steed, Laurence W. Moreland, and Tod A. Baker. New York: Praeger.

Bullock, Charles S., III, and David J. Shafer. 1997. Party Targeting and Electoral Success. Legislative Studies Quarterly 22:573-584.

Bullock, Charles S., III. 2002. Georgia: Another Mixed Partisan Result. In The 2000 Presidential Election in the South: Partisanship and Southern Party Systems in the 21st Century, eds. Robert P. Steed and Laurence W. Moreland. Westport, CT: Praeger.

Bullock, Charles S., III, R.K. Gaddie, and B.H. Smith, III. 2003. White Voters, Black Representation. Paper presented at the annual meeting of the Southwestern Political Science Association, San Antonio, TX.

Clark, John A., and Brad Lockerbie. 1997. Georgia: Two-Party Political Reality! In The 1996 Presidential Election in the South: Southern Party Systems in the 1990s, eds. Laurence W. Moreland and Robert P. Steed. Westport, CT: Praeger.

Frankston, Janet. 2003. Franklin Considers Race for Miller's Senate Seat. Atlanta Journal Constitution, April 12.

Galloway, Jim. 2004. Shape of Democratic Race in State Becomes More Clear. Atlanta Journal Constitution, February 25.

Isakson Press Release. 2004. Democratic Leaders Joined by Partisan Committee for Isakson. October 11.

Lockerbie, Brad, and John A. Clark. 1994. Georgia: A State in Transition. In The 1992 Presidential Election in the South: Current Patterns of Southern Party and Electoral Politics, eds. Robert P. Steed, Laurence W. Moreland, and Tod A. Baker. New York: Praeger.

Lublin, David. 1997. The Paradox of Representation. Princeton: Princeton University Press.

Lublin, David. 2004. The Republican South. Princeton, NJ: Princeton University Press.

Miller, Zell. 2003. A National Party No More. Atlanta, GA: Stroud and Hall.

Quinn, Matthew C. 2004a. Edwards Comes A-Courting Again. Atlanta Journal Constitution, February 29.

Quinn, Matthew C. 2004b. Poll: Kerry Has Lead in Georgia But It's Falling. Atlanta Journal Constitution, February 26.

Rothenberg, Stuart. 2005. Mid-Decade Redistricting: What's Appropriate? Roll Call, January 24.

Scott, Jeffrey. 2004. Bush Visits Atlanta for Ceremony, Fund-Raiser. Atlanta JournalConstitution, January 16. 
Georgia: The GOP Tightens Its Grip | 63

Smith, Ben. 2004a. Majette's Quantum Leap of Faith. Atlanta Journal-Constitution, July 11.

Smith, Ben. 2004b. U.S. Senate Candidate Launches Last-ditch Ado. Atlanta JournalConstitution, June 30.

Tharpe, Jim. 2004. GOP Race Turns to Debate on Abortion. Atlanta Journal-Constitution, January 30 . 
